\title{
China Dream and the Ideological and Political Education of Colleges and Universities: based on Chinese Modern History Outline
}

\author{
Tianhu Yang \\ School of Marxism, Qujing Normal University, Qujing, China \\ yangth358@sina.com
}

Keywords: China Dream; Ideological and Political Education; Colleges and universities

\begin{abstract}
Chinese Dream is an important content of Ideological and political education in Colleges and universities, the integration of the Chinese Dream into the ideological and political theory course can deepen the understanding of the students for Chinese dream, and enhance the effectiveness and pertinence of the ideological and political education in Colleges and universities.
\end{abstract}

\section{Introduction}

As an important crystallization of thought, The Chinese Dream is put forward by the new generation of leadership and leadership of the Communist Party of China, and becomes China's development goal. On November 29, 2012, Xi Jinping, general secretary of the CPC Central Committee, explained the concept of "China Dream" when he visited the "Revival Road" exhibition organized by the National Museum. He said: "Everyone is discussing the Chinese dream. I think that the great rejuvenation of the Chinese nation is the greatest dream of the Chinese nation in modern times. "At the closing ceremony of the First Session of the 12th National People's Congress, Xi Jinping elaborated on the" "and uttered the profound connotation of the Chinese dream: Chinese Dream is to achieve national prosperity, national rejuvenation and people's happiness." The Chinese dream reflects the glorious tradition of our ancestors' relentless pursuit of progress and the dream of the Chinese. The way to achieve the Chinese dream comes from three aspects: (a) to achieve the Chinese dream must take the Chinese road. It is the road of socialism with Chinese characteristics. It is the inevitable result of practical social and historical development, which is from the practice of reform and opening up , the exploration of the People's Republic of China and summing up of the modern Chinese nation course of development. Based on the firm theory of self-confidence, road self-confidence, self-confidence in the system, the Chinese dream can become a reality; (b) to achieve the Chinese dream must carry forward the spirit of China. It is the patriotism as the core of the national spirit to reform and innovation as the core of the spirit of the times.Colleges and universities are the main front of ideological and political education, but also an important platform for propagating party and national policies. China's dream helps to improve the ideological and political education in colleges and universities. Publicity and practice of Chinese dream has become an important subject of ideological and political education in colleges and universities, but also a new content of ideological and political education, which gives the ideological and political theory of the new era characteristics, new practice requirements. About the understanding of the Chinese dream, the author conducted a survey of 100 college students and analyzed the data as follows:

Table 1 College students' cognition of Chinese Dream

\begin{tabular}{|c|c|c|}
\hline option & Number of respondents & proportion \\
\hline knowing deeply & 9 & $9 \%$ \\
\hline knowing a little & 89 & $89 \%$ \\
\hline no knowing & 2 & $2 \%$ \\
\hline
\end{tabular}

College students are an important force in building socialism with Chinese characteristics. As a powerful spiritual strength, Chinese dream is provided spiritual support for young college students, 
helps to shape their world outlook, outlook on life and values. Chinese dream is also a force of cohesion and integration. In the process of practicing the Chinese dream, the individual dream of college students condensed into a centripetal force, which enhances the spirit of the struggle of college students. Chinese dream goes into the university campus, the ideological and political class classroom, By the social practice of Chinese dreams, to students can promote ideological and moral quality, and enhance a correct understanding of China's history and reality, which will deepen the students' Firm belief in socialism and the road of socialism with Chinese characteristics.

\section{Chinese Dream Corresponding to Chinese Modern History Outline}

Ideological and political teaching is an important channel to promote the Chinese dream, and " Chinese Modern History Outline " (hereinafter referred to as "outline") is an important part of ideological and political theory course, The course carry out ideological and political education function from a historical point of view. The Understanding of Chinese dream should be from the development of contemporary and historical development, the intersection of the two is the great rejuvenation of the Chinese nation. "Outline" is an important material carrier which understands the Chinese dream from the perspective of historical development.

From a Macro Perspective, the Chinese Dream is a High Degree of Generalization of Outline Textbook. The meaning of the Chinese dream: the national revitalization and national prosperity, is the main line of Chinese modern history. "China's generation after generation of people with lofty ideals and the people for the salvation and the realization of the great rejuvenation of the Chinese nation and heroic struggle hard to explore the history; People under the leadership of the Communist Party of China fight, through the new democratic revolution, to win the national independence and the liberation of the people; through the socialist revolution, construction and reform, an extremely weak old China gradually become a prosperous, full of vitality and vitality of the new socialist history of China. "The main line is the embodiment of the Chinese dream, the Chinese dream is the main line of concentration and sublimation, the Chinese dream is the inevitable result of the development of Chinese modern history. To understand the Chinese dream, we must "understand the history of the country, understand the national conditions", "the two understanding" is one of the teaching objectives of the "outline", China's modern history and national conditions are precisely the background of China's dream ideas. "Four choices": the choice of Marxism, the choice of the Chinese Communist Party, the choice of socialism, the choice of reform and opening up, They are respectively the guiding ideology, leadership, system assurance and power for achievement of the Chinese dream.

Starting from the Specific, All Aspects of the Chinese Dream Embodied in the "outline" the Contents of Each Chapter. Modern China faces two major historical tasks: national independence and the liberation of the people, the realization of national prosperity, and common prosperity of people, They are the concrete manifestation of the Chinese dream. The emergence of the two historical tasks is precisely the transition from feudal society to semi-colonial and semi-feudal society, the transition from the old democratic revolution led by the bourgeoisie to the new democratic revolution led by the proletariat (mainly through the Chinese Communist Party), and through socialism Revolution, construction and reform, the two major historical tasks are gradually realized, the Chinese dream has gradually become a reality. The Chinese nation was an extraordinary creative nation and created great Chinese civilization. However, in the late period of Qianlong, the Chinese feudal society gradually faded. With the capital-imperialist aggression against China, the social nature of China began to change: Society gradually reduced to semi-colonial and semi-feudal society, since then, modern China showed a situation of poor and weak. It is the background of China's dream, the Chinese dream is to achieve the great rejuvenation of the Chinese nation. Then, the peasant class, the landlord class and the bourgeoisie of China have explored the two historical tasks. However, the feudal relations of production of the small-scale peasantry are not suited to the development of capitalist productive forces, At the same time Because of the weakness of the national bourgeoisie, all lead to early exploration failure, To a 
certain extent, these explorations provide the preparatory work for achieving the Chinese dream. Sun Yat-sen, the pioneer of the Chinese democratic revolution, firstly put forward the slogan of "revitalizing China" and clearly expressed the significance of the great rejuvenation of the Chinese nation. This is a dream of the whole nation. He led the bourgeois revolutionaries, through the Revolution of 1911, overthrowing the Qing dynasty feudal rule, ending of the rule of China monarchy, spreading the concept of democratic republic. In view of the historical process and social conditions, the Revolution did not change the old Chinese semi-colonial and semi-feudal social nature, did not change the tragic situation of the Chinese people, did not complete the historical mission of the national independence and the liberation of the people's, but it greatly promoted the Chinese National ideological emancipation, open the door to the trend of China's progress, for the development and progress of the Chinese nation to explore the road. With the failure of the Revolution of 1911, Chinese society and history called for a new class capable of taking on the task of national rejuvenation. In 1921, there was an "epoch-making event", namely, the establishment of the Communist Party of China, the class mission and the national mission , Bravely bear the great cause of national rejuvenation, the Chinese dream on the right track. Especially in the difficult years of the war of resistance against Japan, the Communist Party of China played the mainstay role. After the war of liberation, the Chinese Communist Party led the people of the whole country to victory in the new democratic revolution and established the People's Republic of China. The first generation of leading groups headed by Mao Zedong realized the second historic change of modern China. In 1954 the first session of the National People's Congress, the Chinese dream began to become clear, Mao Zedong announced a dream: to build a prosperous and modern power struggle. At one meeting of the Third People 's Congress, Zhou Enlai declared four modern goals: to the end of the 20th century, modern agriculture, modern industry, modern science and technology, modern defense power. Under such a dream, our socialist modernization construction has achieved fruitful results, and the national rejuvenation of the distance and a step forward.

\section{Chinese Dream's Integration into the Outline of China's Modern History}

The Outline is from the perspective of historical development to understand the Chinese dream. China Dream into the outline is necessary, its integration process is a systematic process. In this process, we should adhere to the principle of combining theory with practice, step by step to Chinese dream thought into the "outline" teaching, and then increase the outline teaching timeliness.

Designing Teaching Topics with China Dream as the Core. Based on the topic of teaching, combined with the "Chinese dream" thinking, "outline" of the special teaching can be around the "Chinese dream" to design. (1) the historical background of the China Dream; (2) the Revolution of 1911 and the "Chinese Dream"; (3) the realization of the "Chinese Dream" (3) the "Dream of the Chinese Dream" "The guiding ideology and leadership; (4) the Chinese dream budding; (5) the realization of the Chinese dream road. The first topic includes the first chapter and the second chapter, mainly to summarize the history of modern China, especially capital - imperialist aggression, to bring disaster to the Chinese people at the same time, but also to the modern Chinese social nature has changed, The second topic is the third chapter, the main content is Mr. Sun Yat-sen in the "revitalization of China" under the guidance of the slogan, led by the China Dream "proposition of the root causes of the development of the " The Revolution of 1911 opened the door for the progress of Chinese society. The bourgeois revolutionaries, led by Sun Yat-sen, carried out a series of revolutionary activities aimed at achieving the country's prosperity and prosperity. "Revitalization of China" is the growth factor of the Chinese national dream of revival, although the "Chinese dream" at this time is relatively hazy and fuzzy, but it provides an important condition for the later realization of the Chinese Dream; the third topic covers Chapter IV, Chapter 5, Chapter 6 and Chapter 7 the topic is "the outline" directly reflects the two options: the choice of Marxism and the choice of the Communist Party. Marxism is the guiding ideology of the Communist Party 
of China and the important ideological condition for realizing the "Chinese Dream". The establishment of the Communist Party of China has made the "Chinese Dream" a firm leader. In the war of resistance against Japan, the Chinese Communist Party took on the important role of national rejuvenation, played the mainstay role, cooperated with the Kuomintang to establish the anti-Japanese national united front, and finally won the victory of the War of Resistance Against Japan, which is the Chinese people against foreign aggression since modern times The first complete victory of the national liberation war. This made an important contribution to the realization of the "national prosperity, national revitalization" of the Chinese dream; the fourth topic by the eighth and ninth chapter. The establishment of the People's Republic of China, China has achieved national independence and people's liberation. With the victory of the socialist revolution, China established the basic system of socialism, in order to achieve the "Chinese dream" laid the institutional basis. In this period, the first generation of the leading collective of Mao Zedong as the core of the "Chinese dream" clear and specific, that is, to achieve agriculture, industry, science and technology and national defense of the modernization of the dream, which is the seeds of Chinese dreams ; The fifth topic around the tenth chapter content, mainly about the "Chinese dream" to achieve the road. The second generation of the leading collective of the Communist Party of China, led by Deng Xiaoping, reestablished the ideological line of seeking truth from facts, implemented reform and opening up and found a socialist road with Chinese characteristics. China's modernization construction has achieved remarkable achievements. Step by step to the reality, which is from the development of today's reality to understand the "Chinese dream" empirical. On the basis of the "Chinese Dream" of the first generation and the second generation of collective leadership, the general secretary of Xi Jinping, the third generation of collective leadership, put forward the "national dream of national rejuvenation", which has more important significance and will bring China 's prosperity, national rejuvenation and people' $\mathrm{s}$ happiness.

Giving Full Play to Multimedia to Create a Chinese Dream Learning Atmosphere. Multimedia teaching is a modern teaching means, with intuitive, image, large amount of information and other characteristics, and thus, to stimulate students' interest in learning. "Outline" class to historical and historical ideological and political education, including a large number of historical information, such as pictures, video, audio and so on. Multimedia teaching can integrate various teaching resources to improve the timeliness of teaching. In accordance with the "China Dream" topic, the production of illustrations of multimedia courseware, the use of multimedia courseware, the "Chinese dream" ideas directly presented in front of students, targeted teaching. Make full use of video information, including the relevant documentary, film and television information, audio information, etc., teachers in the process of teaching, supplemented by multimedia teaching means, through a historical event documentary information, film and television information, show history, this is more vivid, The image, increased the interest of students to learn, to the students with a direct visual impact. At the same time, by looking at teaching video materials, to guide students to discuss the interaction, to mobilize the attention of students, so that students can improve self-learning ability. In the process of propagating the "Chinese Dream", there are representative video materials for teachers to choose, "Revival of the Road", "Party Albert", "banner", "founding of the great cause", "Deng Xiaoping" and so on. These video materials are important events or important figures on the road of revival of the Chinese nation, and have close ties with the thought of "China Dream". Multimedia courseware and video materials for the "outline" teaching provides an important auxiliary conditions. On the one hand reflects the content of patriotism education; the other side is to promote the "Chinese dream" thought, to create a good learning atmosphere.

Understanding the Chinese Dream by the Social Practice. The Outline is an important ideological and political theory course, in accordance with the "outline" syllabus requirements, practice teaching is also an important part. Social practice to achieve the combination of theory and practice of the material, but also reflects the understanding of the reality from the perspective of "China Dream" requirements. Visit the patriotism education base is an important way to carry out 
social practice, so that students understand the process of national rejuvenation since modern China, especially after the founding of the Communist Party of China, leading the people to win the new democratic revolution, socialist revolution, construction and reform Of the process, this process is the great rejuvenation of the nation's most important part of the journey. On the one hand to increase the recognition of the four options; the other hand, in fact, deepen the understanding of "China Dream". Carrying out the "China Dream" theme education practice is an effective way to practice "Chinese dream". Through the keynote speech, theme essay and other activities to carry out practical education activities. "China Dream" theme of the topic can be set to "China Dream" history, the Chinese Communist Party and the "Chinese Dream", reform and opening up and "Chinese Dream" and so on. The theme of the speech to enable students to integrate the "Chinese dream", the body experience "Chinese dream", the individual dream and the dream of national renaissance together to understand the "Chinese dream" to realize the meaning and role of personal dreams, increase patriotism, And actively participate in the socialist modernization drive with Chinese characteristics. Students combine their own actual situation, around the great course of national rejuvenation, to carry out "China Dream" essay activities

\section{Conclusions}

Writing the writing of modern Chinese people with lofty ideals for the realization of national independence, the liberation of the task, in the historical development of the profound feelings of the "Chinese dream", deeply understand the history and people choose to choose Marxism, choose the Chinese Communist Party, choose socialism, Choose reform and reform and opening up, which is the inevitable development of history and reality, but also to achieve the "Chinese dream" an important condition. To carry out the "Chinese Dream" into the community activities, so that college students become "China Dream" propaganda, deep grassroots understanding of society, to achieve the combination of theory and practice, in practice, intuitive feel "China Dream" to bring great changes in Chinese society and achievement. In short, social practice will make up for the lack of theoretical study, to deepen students' understanding of "Chinese dream".

\section{References}

[1] J.P.Xi: The Governance of China, Foreign Language Press Co.Ltd, Beijing,2014.

[2] Information on http://cpc.people.com.cn.

[3] X.M.Zhu, Analysis of integration of the Chinese dream into the content of the ideological and political education about College Students, Leading Journal of Ideological \& Theoretical Education,(2017)No.3,pp.135-138.

[4] X.K.Cai, Research on the path of integrating Chinese dream into college students' Ideological and Political Education, Journal of Inner Mongolia Normal University (Educational Science),(2017)No.4,pp,51-56.

[5] K.J.Liu, The connotation and characteristics of Chinese dream and the path of IntegratingIdeological and political education into College Students, Education Exploration,pp,74-76.

[6] S.Liu, On the integration of Chinese dream into college students' Ideological and political education, (Jilin University MS., China,2014),p.28. 